\title{
THE PREVALENCE OF ONYCHOMYCOSIS IN THE ZAGREB AREA - THE ROLE OF SABOURAUD AGAR WITHOUT CYCLOHEXIMIDE IN DIAGNOSIS AND THERAPY
}

\author{
Sanja Mendek ${ }^{1}$, Liborija Lugović-Mihić ${ }^{1}$, Iva Ferček ${ }^{1}$, Iva Japundžić ${ }^{1}$, \\ Mirna Šitum ${ }^{1}$ and Maja Abram ${ }^{2}$
}

\begin{abstract}
${ }^{1}$ Department of Dermatovenereology, Sestre milosrdnice University Hospital Centre, Zagreb, Croatia; ${ }^{2}$ Department of Microbiology, School of Medicine, University of Rijeka, Rijeka, Croatia
\end{abstract}

SUMMARY - Mycological analysis is considered the gold standard in the diagnosis of very common fungal diseases of nails. The purpose of the article is to present the prevalence of onychomycosis obtained by using direct microscopic examination (DME) and cultivation on Sabouraud media without cycloheximide. The quantitative retrospective research was conducted on 2706 patients of both sexes (mostly middle-aged to elderly) with various toenail lesions, who had undergone mycological analyses in the Mycological Laboratory of our Department of Dermatovenereology in 2013 and 2014. Analysis of the results obtained revealed that there were $35.4 \%$ of positive DME results; of these, there were $39.2 \%$ of dermatophytes, $59.1 \%$ of yeasts and $1.7 \%$ of molds. The percentage of dermatophytes (Trichophyton spp.) was twice as high in men as in women. A considerable percentage (12\%) of mixed isolates was also observed. Particularly worrisome was the high percentage (one-third) of suppressed and insufficiently developed dermatophytes (a possible indicator of inappropriate preparation of patients for mycological analysis). Cultivation on culture media without cycloheximide requires frequent inspections because of the fast-growing molds while not allowing sporulation for a great number of dermatophytes. However, it has certain advantages, i.e. it offers an insight into the wide range of the present fungi. As part of the biofilm, they can be potentially pathogenic in dystrophic nails under certain circumstances because, according to our results, the percentage of dermatophytes does not change substantially with aging; however, what does change is the percentage of molds, yeasts and mixed isolates.

Key words: Mycological examination; Onychomycosis; Dermatophytes; Nails; Biofilms; Non-dermatophyte fungi

\section{Introduction}

Mycological analysis of toenail samples account for a large percentage of all the requested mycological tests in dermatovenereological laboratories. Their purpose is to establish, isolate and identify the causative

Correspondence to: Sanja Mendek, $M D, P b D$, Department of Dermatovenereology, Sestre milosrdnice University Hospital Centre, Vinogradska c. 29, HR-10000 Zagreb, Croatia

E-mail: sanjamendek@gmail.com

Received May 24, 2017, accepted December 13, 2017 agents of onychomycosis $(\mathrm{OM})$, supervise the successful progress of antimycotic therapies and rule out other pathological processes on toenails.

Onychomycosis is nail infection caused by keratolytic dermatophytes (specifically, tinea unquium) ${ }^{1}$ from the genera Trichophyton, Microsporum and Epidermophyton, yeasts (mostly Candida (C.) albicans, C. tropicalis, C. pseudotropicalis, C. parapsilosis, C. krusei) $)^{2}$ and non-dermatophyte molds ${ }^{3}$, such as Scopulariopsis brevicaulis, Onychocola canadensis, Scytalidium spp., Fusarium spp., Aspergillus spp., and many others ${ }^{4,5}$. 
Based on clinical features of suspected OM, a physician will request mycological analysis. In Croatian laboratories, the gold standard ${ }^{6}$ refers to the direct microscopic examination (DME), usually using a 10\%$30 \%$ potassium hydroxide $(\mathrm{KOH})$ and cultivation on a modified Sabouraud medium (with the addition of antibiotics such as chloramphenicol and gentamicin), with or without cycloheximide, which prevents the growth of certain strains of non-dermatophyte molds and yeasts ${ }^{1,3,7}$. It is a primary medium for isolation of pathogens the identification of which relies on the knowledge of the macroscopic and microscopic characteristics of the grown colonies. Despite the fact that the culture media without cycloheximide have somewhat lost their appeal due to the inability of certain dermatophytes to sporulate, our experience suggests that they can be useful not exclusively for primary sterile samples.

The purpose of this article is to provide an insight into the share of dermatophytes, yeasts and non-dermatophyte molds as potential pathogens in OM, grown on Sabouraud agar without cycloheximide, as well as the prevalence of positive and negative results of DME, and grown isolates, according to patient sex and age.

\section{Patients and Methods}

\section{Patients}

This retrospective study included examining the protocol books of the Department of Dermatovenereology, Sestre milosrdnice University Hospital Centre in Zagreb, specifically, the entries related to mycological analyses carried out over two years (between January 1, 2013 and December 31,2014). Nail samples of 2706 patients were analyzed.

\section{Methods}

Ethical approval from the Sestre milosrdnice University Hospital Centre Ethics Committee (EP11203/15-2) and written informed consent from all patients (including parents or guardians for children) for participation in the study were obtained.

\section{Sampling}

After thorough visual examination of damaged nail/nails, a sterile instrument (a scalpel, curettes of various diameters, tweezers) was used to remove the part of damaged tissue with the highest number of live pathogens. The removed material was chopped up and placed on a slide for DME. A sterile metal spike was used to inoculate part of the specimen (minimum of 10 inocula) onto the nutrient agar (a Sabouraud medium without cycloheximide, Becton-Dickinson, Franklin Lake, US), that was incubated at room temperature for 14 days.

\section{Preparation for DME}

One or two drops of $10 \% \mathrm{KOH}$ were added to the specimen on the slide, covered with a cover glass (22x22 mm), heated over a burner (based on our more than 20-year experience) for a few seconds and, using a finger cushion, gently thinned down to the thickness required for the preparation (a single layer of epithelial cells). Upon cooling down, the preparation is observed under a light microscope (Olympus BX41, Olympus, Tokyo, Japan) at low magnification (10x10), searching for fungal elements among/on the epithelial cells. If hyphae (septate, non-septate) or various forms of spores are found and then confirmed at higher magnification $(10 \mathrm{x} 40)$, it is considered a positive DME result, whereas the potential artifacts that can resemble fungal elements, such as 'mosaic fungus', drops of fat, fibers of varied diameters and small crystals, are considered a negative result.

\section{Cultivation and identification of grown colonies}

During 14-day incubation at room temperature, on days 5, 10 and 14 of culture inoculation, the grown colonies were inspected on Sabouraud agar (without cycloheximide). The colony growth rate, shape, surface texture, color and background color were monitored. A small part of the aerial mycelium containing a fertile structure was placed on the slide with a metal inoculation spike and was examined under the microscope using $10 \% \mathrm{KOH}$ (based on experience). The shapes of hyphae, their thickness, color, septation status, presence of chlamydospores, microconidia and macroconidia, their shape, membrane thickness, their mutual relationship and their relationship with the conidiophore to which they were attached were examined at high magnification (10x40, Olympus BX41, Olympus, Tokyo, Japan). Based on consolidated morphological data, the genus and species of the grown colonies are 
identified. Additional identification tests (sub-cultivation on selected media and biochemical tests) were not carried out.

The results were interpreted as follows:

culture negative - no growth on the nutrient agar;

Candida sp. - abundant growth of unidentified Candida species;

Candida sp. 1 colony - scanty growth or a single colony of unidentified Candida species;

Trichophyton mentagrophytes - well-developed colony of dermatophytes with clear morphology of fertile structure that enables identification down to the species level;

molds - growth recorded in 2 or more species of mold from the same nail sample, identification not carried out;

Trichophyton sp. - moderate growth of dermatophytes the fertile structure of which is either not developed enough to enable positive identification of species or displaying signs of pleomorphism; sterile mycelium;

Trichophyton sp. suppressed growth - very weak and scanty growth; sterile mycelium; and

Scopulariopsis brevicaulis - abundant growth in pure culture (or monoculture) of identified mold.

\section{Data analysis}

The data obtained were processed using SPSS v. 17 statistical software and descriptive statistics methods. The prevalence, figures and percentages of isolates were presented graphically.

\section{Results}

\section{Patient distribution according to sex and age}

The research included toenail samples of $2706 \mathrm{pa}-$ tients with suspected OM. Most of the patients were female, 1715 (63.4\%) versus 991 (36.6\%) male. The patients were distributed in six age groups of $0-6,7-12$, $13-18,19-40,41-65$ and $>65$ years. The $41-65$ age group accounted for almost $50 \%$ of patients; almost one-third of them $(32 \%)$ were in the $>65$ age group, $15 \%$ were aged $19-40$, only few were younger.

\section{$D M E$ results}

Direct microscopic examination results were positive in 957 (35.4\%) samples. Positive microscopic re- sults were slightly more common in men (39.8\%) than in women (32.8\%). The prevalence of positive DME results increased progressively with patient age and was highest in patients aged $>65$.

\section{Cultivation results}

Fourteen days after the sample had been inoculated onto Sabouraud agar, the culture media remained sterile in 1359 (50.2\%) cases, although 20.3\% of them were DME positive. The positive cultures were predominated by molds, followed by various Candida species, either in pure (166 samples) or in mixed culture with other molds or dermatophytes (128 samples). As for dermatophytes, Trichophyton spp. was isolated in most cases (with Trichophyton mentagrophytes having the highest frequency as it was identified in 73 samples). As many as 97 samples of Trichophyton spp. manifested suppressed growth; a partly developed aerial mycelium was identified in 90 samples. Growth of potentially pathogenic non-dermatophyte molds was recorded for Scopulariopsis brevicaulis $(\mathrm{n}=5)$, Aspergillus spp. (n=3) and Fusarium spp. (n=3) (Fig. 1). Of all positive culture results, $33.3 \%$ were $\mathrm{DME}$ negative.

\section{Cultivation results according to the share of dermatophytes, yeasts and molds}

\section{Dermatophytes}

In this study, only the genus Trichophyton spp. was isolated, of which only one-third of the samples were identified well (the most frequent being Trichophyton (T.) mentagrophytes, plus a low percentage of T. rubrum and T. violaceum). Trichophyton spp. (their growth being either suppressed or identified only down to the genus level) accounted for the remaining two-thirds (Fig. 2). Its overall distribution by age groups did not exhibit any relevant differences in patients who were not adolescents (Fig. 3). However, separate analysis of the suppressed growth revealed a tendency of the suppressed Trichophyton spp. to decrease with patient age.

\section{Yeasts}

Yeasts were a very common isolate on culture media without cycloheximide, their main representative being Candida spp. It equally grew in pure culture (39.52\%) and combined (38.57\%) with molds (more often) and dermatophytes. It also exhibited progressive growth with patient age (Figs. 4 and 5) and had the 


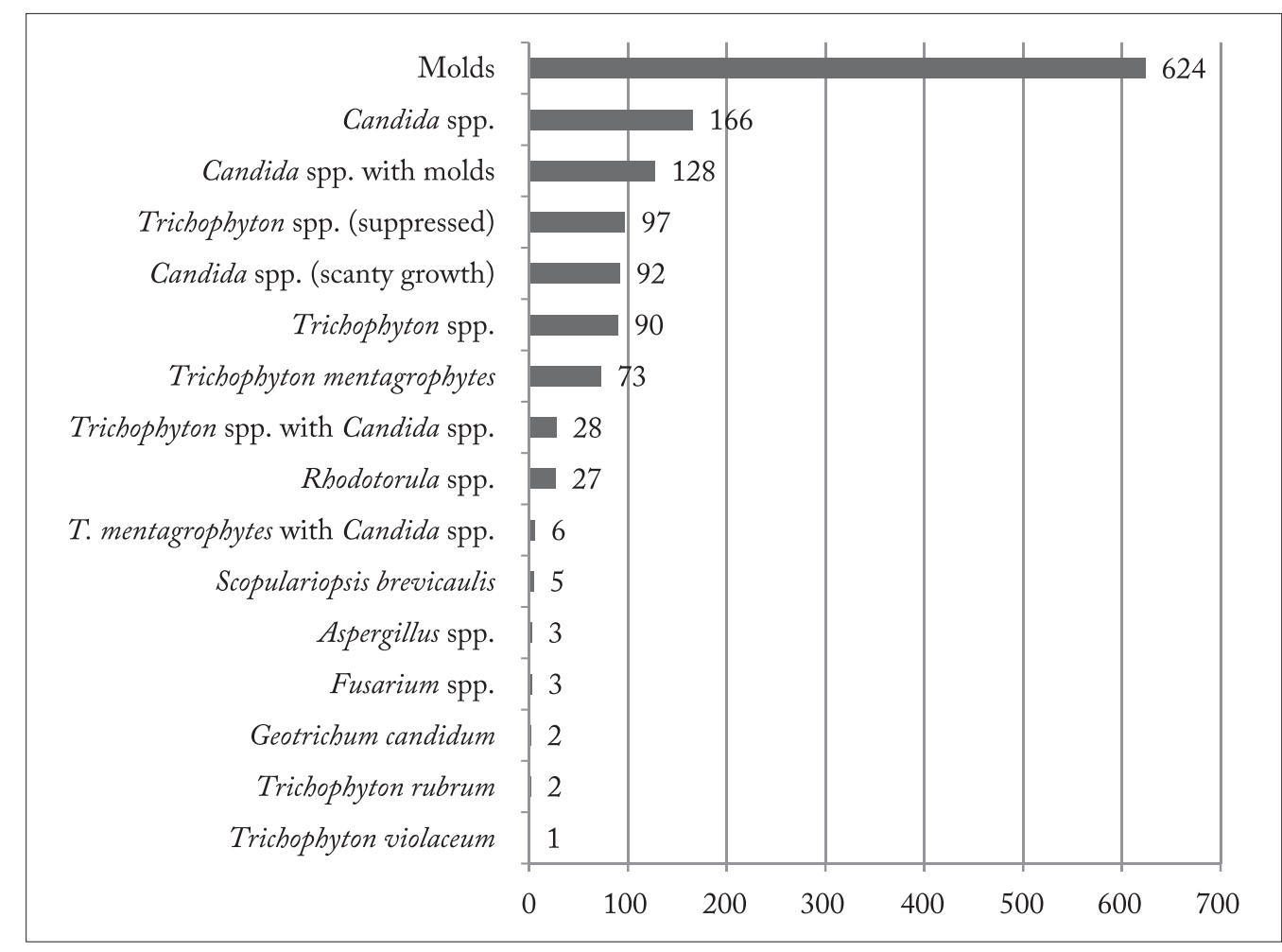

Fig. 1. Prevalence (n) of isolates on Sabouraud agar (Becton-Dickinson) without cycloheximide.

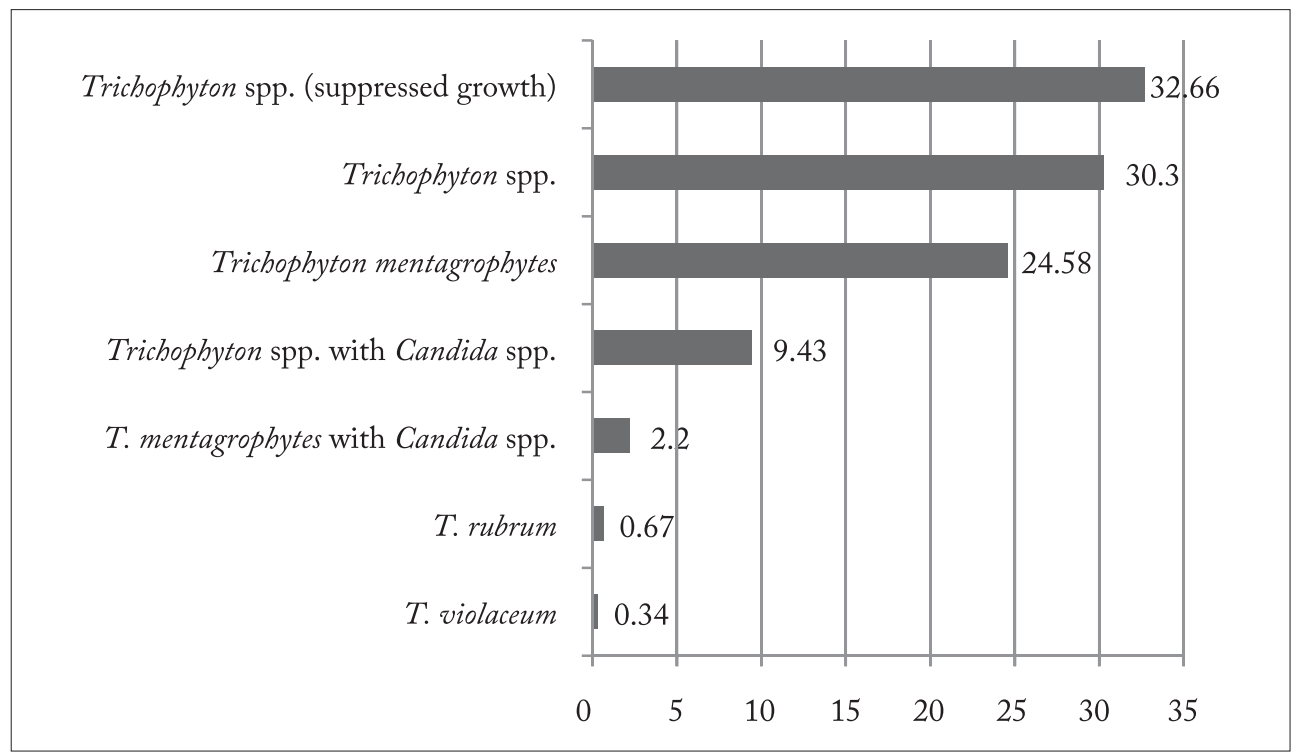

Fig. 2. Prevalence (\%) of isolated dermatophytes $(n=297)$.

highest frequency in patients aged $>65$. One-fifth (21.9\%) of the isolated Candida spp. exhibited very scanty growth.
Molds

As the molds growing in pure culture can be considered potentially pathogenic, their identification was 


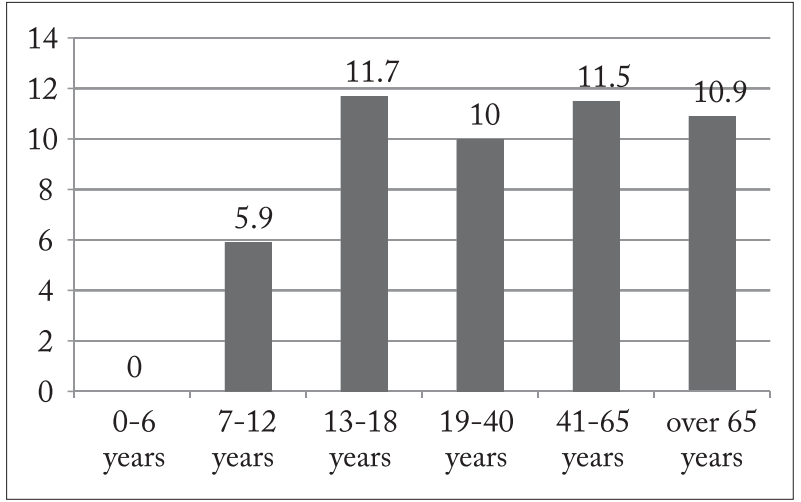

Fig. 3. Distribution (\%) of all isolated dermatophytes according to age.

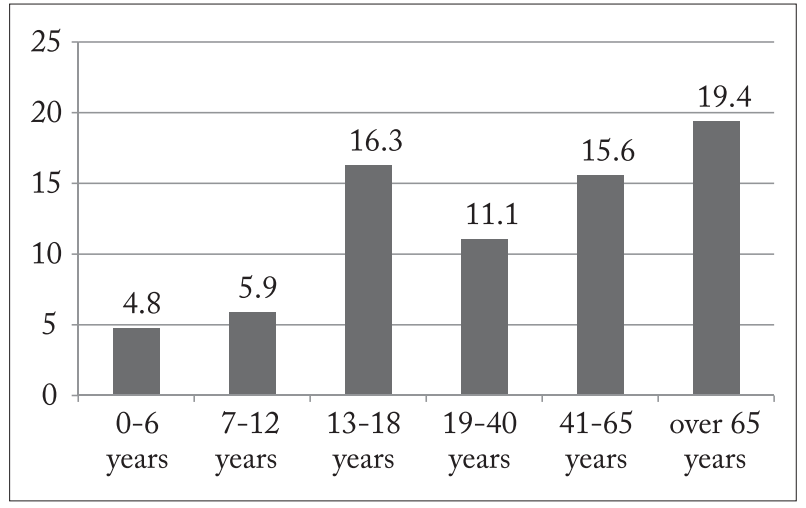

Fig. 4. Distribution (\%) of isolated Candida spp. according to age.

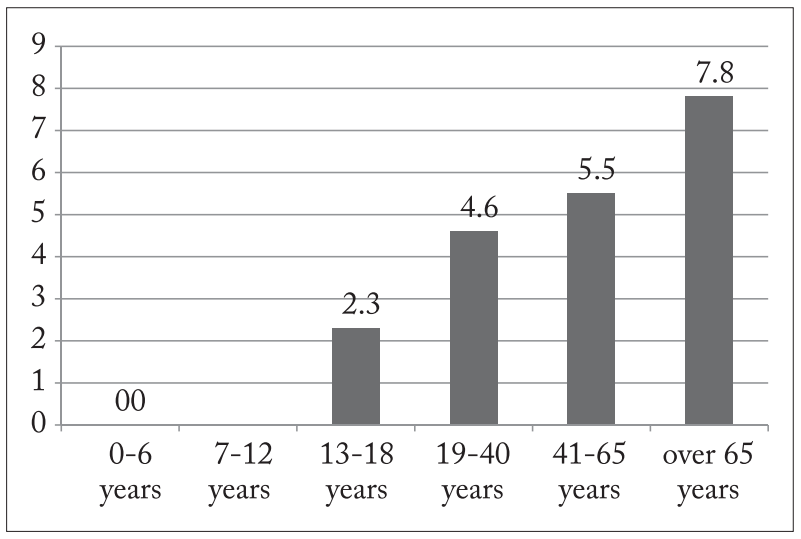

Fig. 5. Distribution (\%) of mixed isolates according to age.

carried out. The most frequent isolates were Scopulariopsis brevicaulis (38.46\%), followed by Aspergillus spp. and Fusarium spp. in similar percentages (23.07\%).

Pure culture molds appeared only in the 19-40 age group and their presence grew progessively with age

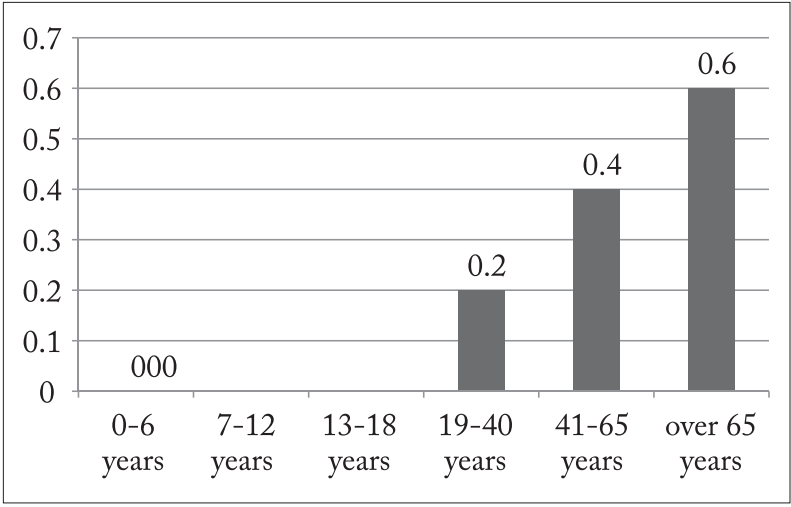

Fig. 6. Distribution (\%) of grown molds in pure culture according to age.

(Fig. 6), unlike unidentified molds that were present in all age groups, although they showed a trend of growing with patient age.

\section{Cultivation results according to patient sex}

The lower percentage of negative cultures in men (44.5\%) compared to women (53.5\%) was accompanied by a higher percentage of the total of isolated dermatophytes (almost double). The percentage of Trichophyton spp. exhibiting a suppressed growth was somewhat higher in men than in women. In women, on the other hand, the rather rare Trichophyton spp., such as $T$. rubrum and T. violaceum, were isolated. No major differences were observed in other categories (Fig. 7).

\section{Discussion}

The diagnosis of $\mathrm{OM}$ as a pathologic nail condition caused by a wide range of etiologic agents (from keratolytic dermatophytes to yeasts and molds) is based on visualization of the agent itself using direct microscopic examination, and its cultivation, isolation and identification on one of the available culture media.

The first information on a potential fungal infection a clinician obtains upon requesting mycological analysis are DME results. Some authors estimate that DME results are false-negative in $5 \%-15 \%$ of cases ${ }^{7}$, depending on the method used. The most frequently used clearing reagent is a $\mathrm{KOH}$ solution, in concentrations varying from $10 \%^{7}$ to $40 \% \%^{8,9}$, depending on the thickness of keratin sample and length of preparation.

In our study, positive DME results were obtained in $35.4 \%$ of cases, somewhat more frequent in men 


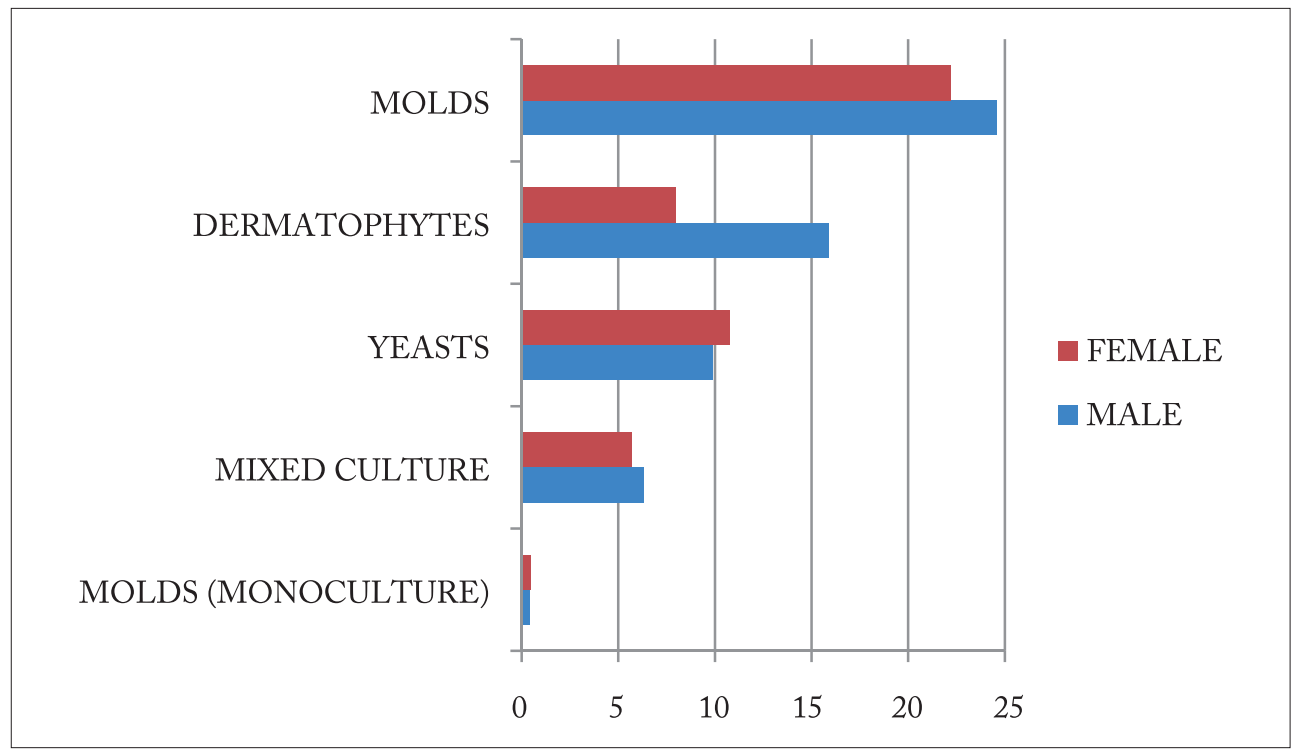

Fig. 7. Prevalence (\%) of individual groups of isolates according to gender.

than in women, which corresponded to the higher frequency of negative cultures in women (53.5\%) than in men (44.5\%). Women accounted for almost two-thirds of patients (63.4\%), indicating that they tend to seek medical help more often (probably for aesthetic reasons) and are more concerned about damaged nails than $\operatorname{men}^{10}$, notwithstanding that their percentage of isolated dermatophytes was twice lower (8.0\%) that found in men (15.9\%).

According to the literature ${ }^{1}$, most $\mathrm{OM}$ (as much as 90\%) are caused by dermatophytes, whereas the remaining $\mathrm{OM}$ are caused by yeasts and non-dermatophyte molds. In the past years, however, there have been growing indications that certain species of mold also contribute substantially to the pathogenesis of OM, such as Scopulariopsis brevicaulis and Scytallidium spp., believed to cause keratolysis ${ }^{4,11}$. Varying incidence of non-dermatophyte molds (NDM) can be found in the literature, e.g., less than 1\% (The Netherlands), 2.78\% (Morocco), 4.8\% (Argentina), 7\% (Estonia), $12.4 \%$ (Columbia), 25\% (Pakistan), $59.4 \%$ (Egypt), and $84.7 \%$ (Korea ${ }^{12-19}$. These differences can largely be attributed to climate and geographic characteristics; the highest percentage of the reported NDM isolates come from tropical and subtropical countries 5 . In our research, the molds that grew in pure culture and were thus identified as a potential pathogen made up $1.7 \%$ of all isolates. The one that occurred most frequently was Scopulariopsis brevicaulis (38.5\%), followed by Aspergillus spp. and Fusarium spp. After the 10-year research conducted by the Croatian Reference Laboratory for Dermatological Mycology and Parasitology, it was established that the prevalence of NDM, specifically Aspergillus spp., was 1\%, which is similar to our results ${ }^{10}$.

One of the reasons for variations in the percentage of isolates in the research conducted around the world is the lack of a standardized methodology $y^{7}$, both for preparation of DMEs and for selection of the cultivation medium. The media with cycloheximide (Actidion $\left.{ }^{\circledR}\right)$ do not allow growth of some species such as Scopulariopsis brevicaulis, Aspergillus spp., C. tropicalis ${ }^{3}$, C. pseudotropicalis and C. cruse $i^{2}$. On the other hand, the media without cycloheximide enable growth of the fast-growing molds that can grow over and cover the slow-growing dermatophytes in as many as 20\% of cases $^{7}$. Since modified Sabouraud media without cycloheximide are used in our clinical practice, a high percentage of mold growth (46.3\%) was recorded and we can assume that they also contained some hidden dermatophytes. However, such correlation with positive $\mathrm{DME}$ results is an indication for a clinician that another mycological analysis should be performed after topical therapy and pedicure. Some of these problems would be solved with the use of Littman Oxgall agar, which reduces the growth of fast-growing molds ${ }^{4,7}$, despite its rather low susceptibility (only $23 \%)^{20}$. 
There is also an increasing growth of mixed infections of dermatophytes with non-dermatophyte isolates, ranging from $5 \%$ to $11 \%{ }^{4}$. At the same time, the presence of various species in biologic samples has been confirmed by the experimental methods of immunohistochemistry and flow cytometry ${ }^{21}$. However, debate whether these are co-pathogens or merely colonizers of nail lesions by dermatophytes is still ongoing. The percentage of mixed cultures (combinations of dermatophytes with Candida spp. and Candida spp. with molds) was $12 \%$ and should not be neglected, particularly if the patient is an immunocompromised person, a diabetic or a person receiving hemodialysis ${ }^{22}$. Similar is in the case of Rhodotorula spp., which, in principle, is not considered pathogenic. However, since it is associated with catheter-related biofilm infections $^{3}$, it is reported in our findings. It is presumed that dermatophytoma, a thick, dense network of fungal elements located in subungual spaces between the nail plate and nail bed, is an ideal site for biofilm infection $^{21}$. By many of its characteristics, OM resembles a biofilm infection; these are long-term, recurring infections resistant to therapies. Also, the nail plate prevents their desiccation, thus preserving a high percentage of moisture ${ }^{5}$. Just like the biofilm site should be eliminated in cases of biofilm infections, many authors believe that OM can be cured only by avulsion (mechanical, chemical or surgical) of the nail ${ }^{4,9,23}$, together with combined systemic and topical therapies. Since therapy is usually painstaking and lengthy (from three months with a systemic antimycotic to 18 months with topical therapy $)^{1,3,4,6,11}$, particular attention should be paid to the factors which are important for reaching an accurate diagnosis. One of them is to prepare the patient (in order to reduce the number of false-positive and false-negative results) and the other is to standardize the criteria for deciding whether an isolate is pathogenic or not.

Ideally, a sample should be inoculated onto both types of culture media (with and without cycloheximide $)^{4,7-9,18,20}$ and the pathogenic nature of an isolate should be confirmed by successive sampling and cultivation $^{7,8,11}$. The duration of the recommended successive sampling ranges from a few $(2-5)$ days $^{8}$ to two months ${ }^{9}$. Also, there are numerous differences in the length and temperature (from room temperature to 30 ${ }^{\circ} \mathrm{C}$ ) of culture incubation. Whereas some authors recommend protocols with two-week incubation ${ }^{19}$, others think that incubation should be extended to three $e^{4,8,9,24}$, four $^{18,20,25}$, or five weeks ${ }^{22}$. Some authors believe that most dermatophytes grow within two weeks, and fourweek incubation is recommended for $T$. verrucosum and Onychocola canadensis mold (a common causative agent of $\mathrm{OM}$ in northern Europe and America) ${ }^{7}$.

However, for successful outcome of mycological analysis, most important is appropriate preparation of the patient and correct sampling technique. This should include restraining from any therapeutic preparations, but also from cosmetic and alternative preparations (the ingredients of which could affect the growth and morphology of fungi), such as essential oils, vinegar solutions, citric acid (reducing $\mathrm{pH}$ to a level far from optimal for cultivation) and other remedies from the medicine chest ${ }^{26}$. The restraint period upon completion of antimycotic therapy recommended in the literature varies significantly from five days ${ }^{6}$ to four weeks ${ }^{18}$, and as long as four months ${ }^{8}$. The restraint period recommended to patients in our laboratory is seven days; however, it is difficult to verify to what extent the instructions are really followed. Suppressed growth of dermatophytes (obtained in onethird of our cases), partially developed dermatophytes (one-third) and scanty growth of Candida spp. (onefifth) indicate remaining traces of some active substances. It could be speculated that a significant part of DME positive findings with negative-culture outcome (20.3\%) was the result of nonviable fungal filaments.

The percentage of isolated molds and mixed isolates grows progressively with patient age, which can be explained by two factors. One is comorbidity of chronic diseases in elderly patients caused by reduced immunity, poor peripheral circulation and innervation of feet (e.g., in case of diabetes), which, in turn, is connected with toenail dystrophy $22,27,28$. The other one is elderly people's inability to take appropriate care of their toenails themselves, which significantly decreases the quality of life and psychological state of these patients ${ }^{29-31}$. In order to reduce the percentage of molds considered contaminants, it is recommended to advise elderly and disabled persons with neglected toenails to undergo professional pedicure 7 to 14 days before sampling and then to restrain from using topical preparations until mycological analysis. In such case, the isolate that meets the criteria for NDM can be considered pathogenic and should be eradicated. 
Compared to the above mentioned ten-year retrospective study by the Croatian Reference Laboratory for Dermatological Mycology and Parasitology that identified $80 \%$ of dermatophytes, $19 \%$ of yeasts and $1 \%$ of $\mathrm{NDM}^{10}$, the ratio in our research was somewhat different, i.e. yeasts $59.1 \%$, dermatophytes $39.2 \%$, and NDM 1.7\%. The higher percentage of Candida spp. can be explained by cultivation on the media without cycloheximide, enabling growth of a wider spectrum of yeasts. Although tinea unguium can be caused by dermatophytes of the genera Trichophyton, Epidermophyton and Microsporum, only Trichophyton spp. was isolated in those two years. The most common species was T. mentagrophytes. According to the literature, the number of OM grows progressively with age $\mathrm{e}^{6}$. In our case, the percentage of Trichophyton spp. above age 13 showed no major departures (it varied from 10\% to 11.7\%). However, a progressive growth of yeasts, mixed isolates and molds was observed. In our study, there was no increase in the incidence of T. rubrum ${ }^{10}$. However, we can suppose that some T. rubrum were 'hidden' in the categories of suppressed and partly identified Trichophyton spp. because this species is associated with deep, long-term $\mathrm{OM}^{32}$ likely to have been treated with some remedy already.

Although $\mathrm{OM}$ is a relatively benign disease and rarely causes complications, it may have great impact on the patient psychological state and quality of life ${ }^{29-}$ 31. Thus, successful treatment of this disease based on suitable diagnosis can be very important for the patient.

\section{Conclusions}

The study sample included 2706 patients, twothirds of them women. Almost half of the patients were between 41 and 65 years of age and almost onethird were aged $>65$. DME results were positive in $35.4 \%$ of cases (somewhat more frequent in male patients) and increased progressively with age.

Two hundred and ninety-seven (39.2\%) dermatophytes, 447 (59.1\%) yeasts and 13 (1.7\%) molds grown in pure culture were isolated by cultivation. Considering their distribution according to sex and age, a higher percentage of dermatophytes was observed in men (mostly regardless of age). Sex distribution of yeasts and molds was relatively even, however, showing a ten- dency to increase with patient age, and so did the incidence of mixed isolates.

A particularly interesting result of this research was a high percentage of suppressed (almost one-third) and incompletely identified (more than one-third) dermatophytes, and scanty growth of Candida spp. (around one-fifth), which could be a consequence of inappropriate patient preparation for mycological analyses.

Our results showed that choosing a culture medium without cycloheximide resulted in a higher percentage of isolated molds and yeasts and, consequently, a higher percentage of mixed isolates that could indicate biofilm infection of toenails.

\section{References}

1. Elewsky BE, Hughey LC, Sobera JO, Hay RJ. Fungal diseases. In: Bolognia JL, Jorizzo JL, Schaffer JV, editors. Dermatology. $3^{\text {rd }}$ edn. Elsevier Saunders, Philadelphia; 2012. pp. 1251-66.

2. Delacrétaz J, Grigoriu D, Ducel G. Color Atlas of Medical Mycology. Hans Huber Publishers, Bern; 1976. pp. 13-90.

3. Korting HC. Fungal infections. In: Burgdorf W, Plewig G, Wolff H, Landthaler M, editors. Braun-Falco's Dermatology. $3^{\text {rd }}$ edn. Springer Medizin Verlag, Heidelberg; 2009. pp. 205-37.

4. Vander Straten MR, Balkis MM, Ghannoum M. The role of nondermatophyte molds in onychomycosis: diagnosis and treatment. Dermatol Ther. 2002;15:89-98, doi: 10.1046/j.1529-8019.2002.01522.x

5. Tasić S, Stojanović S, Poljački M. Etiopatogeneza, klinička slika i dijagnostika onihomikoza. Med Pregl. 2001; 54(1-2): 45-51. (in Serbian)

6. Skerlev M. Dermatomikoze. In: Šitum M, editor. Smjernice u dijagnostici i liječenju najčešćih dermatoza i tumora kože. Naklada Slap, Zagreb; 2012.pp. 21-7. (in Croatian)

7. Robert R, Pihet M. Conventional methods for the diagnosis of dermatophytosis. Mycopathologia. 2008;166(5-6):295-306. doi: 10.1007/s11046-008-9106-3

8. Fernandes Meireles TE, Gadelha Rocha MF, Nogueira Brilhante RS, Aguiar Cordeiro R, Costa Sidrim JJ. Successive mycological nail tests for onychomycosis: a strategy to improve diagnosis efficiency. Braz J Infect Dis. 2008;12(4):333-7.

9. Tosti A, Piraccini BM, Lorenzi S. Onychomycosis caused by nondermatophytic molds: clinical features and response to treatment of 59 cases. J Am Acad Dermatol. 2000;42(2): 217-24. doi: 10.1016/S0190-9622(00)90129-4

10. Miklić P, Skerlev M, Budimčić D, Lipozenčić J. The frequency of superficial mycoses according to agents isolated during a ten-year period (1999-2008) in Zagreb area, Croatia. Acta Dermatovenerol Croat. 2010;18(2):92-8. 
11. Elewski BE. Onychomycosis: pathogenesis, diagnosis, and management. Clin Microbiol Rev. 1998;11(3):415-29.

12. Staats CC, Korstanje MJ. Fungi causing onychomycoses in The Netherlands. Ned Tijdschr Geneeskd. 1994;138(47):2340-3.

13. Hajoui FZ, Zeroual Z, Ghfir B, Moustachi A, Lyagoubi M, Aoufi S. The mould onychomycosis in Morocco: about 150 isolated cases in 20 years. J Mycol Med. 2012;22(3):221-4. doi: 10.1016/j.mycmed.2012.05.001

14. Reloso S, Arechavala A, Guelfand L, Maldonado I, Walker L, Agorio I, et al. Onychomycosis: multicentre epidemiological, clinical and mycological study. Rev Iberoam Micol. 2012; 29(3):157-63. doi: 10.1016/j.riam.2011.11.003

15. Järv H, Naaber P, Kaur S, Eisen M, Silm H. Toenail onychomycosis in Estonia. Mycoses. 2004;47(1-2):57-61.

16. Escobar ML, Carmona-Fonseca J. Onychomycosis by common non-dermatophyte moulds. Rev Iberoam Micol. 2003;20(1): 6-10.

17. Malik NA, Raza N, Nasiruddin. Non-dermatophyte moulds and yeasts as causative agents in onychomycosis. JPAD. 2009; 19:74-8.

18. El Batawi MM, Arnaot H, Shoeib S, Bosseila M, El Fangary M, Helmy AS. Prevalence of non-dermatophyte molds in patients with abnormal nails. EDOJ. 2006;2(1):1-12.

19. Hwang SM, Suh MK, Ha GY. Onychomycosis due to nondermatophytic molds. Ann Dermatol. 2012;24(2):175-80. doi: 10.5021/ad.2012.24.2.175

20. Lawry MA, Haneke E, Strobeck K, Martin S, Zimmer B, Romano PS. Methods for diagnosing onychomycosis: a comparative study and review of the literature. Arch Dermatol. 2000;136(9):1112-6.

21. Burkhart CN, Burkhart CG, Gupta AK. Dermatophytoma: recalcitrance to treatment because of existence of fungal biofilm. J Am Acad Dermatol. 2002;47:629-31.

22. Lamb FM, Ottonelli Stopiglia CD, Vetoratto G, Goldani JC, Scroferneker ML. Frequency of onychomycosis in chronic re- nal failure patients undergoing hemodialysis in Porto Alegre, Brazil. Acta Dermatovenerol Croat. 2013;21(1):19-23.

23. Lecerf P, Andre J, Richert B. Management of onychomycosis. Presse Med. 2014;43(11):1240-50.

doi: 10.1016/j.lpm.2014.06.012

24. Rezusta A, de la Fuente S, Gilaberte Y, Vidal-García M, Alcalá L, López-Calleja A, et al. Evaluation of incubation time for dermatophytes cultures. Mycoses. 2016;59(7):416-8. doi: $10.1111 /$ myc. 12484

25. Kaštelan M, Utješinović-Gudelj V, Prpić-Massari L, Brajac I. Dermatophyte infections in Primorsko-Goranska County, Croatia: a 21-year survey. Acta Dermatovenerol Croat. 2014; (22)2:175-9.

26. Vladimir-Knežević S, Kalođera Z, Pepeljnjak S, Blažević N, Hazler K. Activity of essential oil and ethanolic extract isolated from Micromeria thymifolia (Scop.) Fritsch against dermatophytes. Period Biol. 1994;4:383-5.

27. Hamm H. Diseases of nails. In: Burgdorf W, Plewig G, Wolff $\mathrm{H}$, Landthaler M, editors. Braun-Falco's Dermatology. $3^{\text {rd }}$ edn. Springer Medizin Verlag, Heidelberg; 2009. pp. 1060-78.

28. Testi A, Piraccini BM. Nail disorders. In: Bolognia JL, Jorizzo JL, Schaffer JV, editors. Dermatology. $3^{\text {rd }}$ edn. Elsevier Saunders, Philadelphia; 2012. pp. 1129-47.

29. Pires CA, Cruz NF, Lobato AM, Sousa PO, Carneiro FR, Mendes AM. Clinical, epidemiological and therapeutic profile of dermatophytosis. An Bras Dermatol. 2014;89(2):259-64.

30. Lugović-Mihić L, Ljubešić L, Mihić J, Vuković-Cvetković V, Šitum M. Psychoneuroimmunologic aspects of skin diseases. Acta Clin Croat. 2013;52(3):337-45.

31. Brtan-Romić R, Brtan A, Romić I, Cvitanović H, Duvančić T, Lugović-Mihić L. Quality of life and perception of disease in patients with chronic leg ulcer. Acta Clin Croat. 2015;54(3): 309-14.

32. Pierard G, Arrese Estrada J, Pierard-Franchimont C, Quatresooz P. Onychomycosis under the microscope. Janssen Pharmaceutica; 2003. 


\title{
Sažetak \\ UČESTALOST ONIHOMIKOZE NA PODRUČJU ZAGREBA - ULOGA SABOURAUD AGARA BEZ CIKLOHEKSIMIDA U DIJAGNOSTICI I TERAPIJI
}

\author{
S. Mendek, L. Lugović-Mibić, I. Ferček, I. Japundžić, M. Šitum i M. Abram
}

Mikološka obrada smatra se zlatnim standardom pri dijagnosticiranju vrlo čestih gljivičnih bolesti noktiju i predstavlja temelj za propisivanje antimikotične terapije. Cilj ovoga rada bio je ispitati učestalost onihomikoza na temelju izrade izravnog mikroskopskog preparata i kultivacije uzoraka na Sabouraud podlogama bez cikloheksimida. Provedeno je kvantitativno retrospektivno istraživanje na 2706 ispitanika oba spola kojima je učinjena mikološka obrada zbog različitih vrsta oštećenja noktiju stopala tijekom 2013. i 2014. godine u Mikološkom laboratoriju Klinike za kožne i spolne bolesti Kliničkoga bolničkog centra Sestre milosrdnice u Zagrebu. Analizom dobivenih rezultata utvrđeno je 35,4\% pozitivnih izravnih mikroskopskih preparata i izolirano 297 (39,2\%) dermatofita, 447 (59,1\%) kvasnica i 13 (1,7\%) plijesni kao potencijalnih uzročnika onihomikoza. Dermatofiti (Trichophyton spp.) nađeni su u dvostruko većem postotku kod muškog spola. Primijećen je i visok postotak miješanih izolata (12\%). Naročito zabrinjava visok postotak suprimiranih (jedna trećina) i nedovoljno razvijenih dermatofita, što se može tumačiti kao pokazatelj nedostatne pripremljenosti bolesnika za mikološku obradu. Iako kultivacija na hranjivim podlogama bez cikloheksimida zahtijeva učestalu inspekciju zbog brzorastućih plijesni, ona ipak nosi određene prednosti. Prvenstveno pruža uvid u širi spektar prisutnih gljiva koje, kao dio biofilma u oštećenim noktima, mogu biti potencijalno patogene u određenim okolnostima. Naime, prema našim rezultatima, sa starenjem populacije ne mijenja se značajno postotak dermatofita, nego se mijenja postotak plijesni, kvasnica i miješanih izolata.

Ključne riječi: Mikološka analiza; Onihomikoze; Dermatofiti; Nokti; Biofilmovi; Nedermatofitne gljive 